\title{
The Adolescent Religious Coping Questionnaire. Translation and Cultural Adaptation of Pargament's RCOPE Scale for Polish Adolescents
}

\author{
Elżbieta B. Talik
}

Published online: 20 January 2011

(C) The Author(s) 2011. This article is published with open access at Springerlink.com

\begin{abstract}
The paper presents the process of translation and cultural adaptation of the Religious Coping Questionnaire (the RCOPE) by Pargament et al. (2000) for Polish adolescents. The work was driven by the necessity to obtain a structural and measurement equivalence between the American and Polish versions of the instrument. The Polish version was created at the Department of Clinical Psychology of Children and Adolescents at The John Paul II Catholic University of Lublin, Poland. The exploratory factor analysis with the Oblimin oblique rotation was carried out. The principal components method was used as an extraction method of common factors. The results provided input for constructing the scales. The Adolescent Religious Coping Questionnaire consists of 105 items, grouped in 16 scales, which reflects positive and negative religious coping strategies.
\end{abstract}

Keywords Translation $\cdot$ Cultural adaptation $\cdot$ Religious coping $\cdot$ Adolescents

\section{Introduction}

Since the publication of Pargament's (1997) book interest in religious coping topic has increased dramatically. Various studies in this field have been conducted among different age groups (e.g. Benore et al. 2008; Bjorck and Thurman 2007; Dew et al. 2010), not just in the Christian population but also among different religious groups (Abu Raiya et al. 2008; Amer et al. 2008; Rosmarin et al. 2009; Tarakeshwar et al. 2003) almost all over the world (e.g. Huang et al. 2009; Winter et al. 2009; Zwingmann et al. 2008). Research focuses on multiple issues, e.g. religious coping with cancer (Nairn and Merluzzi 2003; Yoshimoto et al. 2006), chronic illness (Cigrang et al. 2003), chronic pain (Dunn and Horgas 2004), HIV (Cotton et al. 2006; Jacobson et al. 2006; Pargament et al. 2004b). Research that documents a positive role of religion in coping with psychiatric problems is becoming more and more popular (e.g. Huguelet et al. 2007; Mohr et al. 2007; Pieper

\section{E. B. Talik $(\bowtie)$}

Department of Clinical Psychology of Children and Adolescent, The John Paul II Catholic University of Lublin, Al. Racławickie 14, 20-950 Lublin, Poland

e-mail: etalik@kul.pl 
2004). There are numerous studies regarding religious coping with some specific stressors such as bereavement (Stoebe 2004), domestic violence (Watlington and Murphy 2006), abortion (Major et al. 1998), widowhood (Michael et al. 2003), and even religious coping with flood (Smith et al. 2000) or hurricane Katrina (Henderson 2010). All above-mentioned studies suggest that religion can play an important role in the process of coping with stress, and religious coping strategies are specific, integral part of this process.

However, religious coping can be both positive and negative. In general, positive religious coping is related to better functioning, and negative religious coping is associated with a number of negative outcomes (Ano and Vasconcelles 2005). For example, positive religious coping is associated with better physical health (e.g. Harris et al. 2008), decreased levels of depression (e.g. Bjorck and Thurman 2007; Koenig and Cohen 1992), increased mental health status (Pargament et al. 2004a, b), and stress related growth (Park and Fenster 2004). Negative religious coping is associated with poorer psychological adjustment and different types of psychopathology, including anxiety, depression, obsessivecompulsive disorder (Ano and Vasconcelles 2005; Conners et al. 2006; Harrison et al. 2001; Sherman et al. 2005). Some of the negative religious strategies could be associated with greater distress or even lead to worsening of health or higher mortality (Pargament et al. 2004a, 2003). It is worth noticing that religious coping significantly predicts outcomes even when controlling for general coping measures (e.g. Pargament 1990a, b) and general religiousness measures (Pargament et al. 1998).

The research to date has focused primarily on adults, without particular regard to religious coping among children and adolescents. There are some studies that attempt to assess if and how youths use religious coping strategies in dealing with different stressors, e.g. parental divorce (Shortz and Worthington 1994) or parental death (Pinnow 2001), sexual assault (Frazier et al. 2004), serious illness such an asthma (Benore et al. 2008), cystic fibrosis (Pendleton et al. 2002) or depression (Carleton et al. 2008; Dew et al. 2010). Wills et al. (2003) found that turning to religion when adolescents are faced with negative life events buffers the impact of life stress on substance use. Molock et al. (2006) have reported that religious coping protects African American adolescents from suicide. These studies support the relevance of religious coping for the young and, in general, are consistent with reports from several studies of adults: positive religious coping correlates positively with indicators of adjustment (i.e. positive affect and life satisfaction) and negatively with indicators of psychological distress (i.e. negative affect and clinical symptomatology).

To date, the issue of religious coping has not been very popular in Poland. There are some investigations that evaluate the role of religion in people's lives (e.g. Chlewiński 1982a, b; Jarosz 2003; Prężyna 1981; Walesa 2006), but usually it is global indicators of religiousness that have been used to measure religion. These methods of assessment are inefficient, because they leave unanswered important questions about the role of religion in the coping process (Pargament 1997). It is a well-known fact that the Religious Coping Questionnaire (the RCOPE) by Kenneth I. Pargament compensates for the lack of a measurement that would evaluate the role of religion in coping with stress. There are many advantages of this instrument, if compared with general methods of assessment. First, the RCOPE is theory-based and function-oriented. This method assesses the most important functions of religion such as finding meaning, gaining control, gaining closeness to God and intimacy with others and achieving a life transformation. Second, the RCOPE is opened to the negative as well as positive side of religion-some religious coping strategies could be ineffective in the coping process. Moreover, some of them could be associated with a higher level of distress or even lead to worsening of health or higher 
mortality (Pargament et al. 2004a, 2003). Next, the RCOPE is detailed and comprehensive in scope as it measures a wide array of religious coping activities, because the nature of religion is multifunctional. Finally, the RCOPE is empirically based, but clinically valid and meaningful (Pargament 1997; Pargament et al. 2000).

There were two main reasons for undertaking the translation and cultural adaptation of the RCOPE in Poland. First and the most important reason was lack of proper measurement that would fully evaluate the role of religion in coping with negative life events. There is one Polish version of the RCOPE, adopted by Paweł Socha, yet it is designed only for adults (Socha 1995, 1997, 2000b). It is known that adolescence is an essential period for the study of religion (van Dyke et al. 2009). During this time, religious development and maturation takes place, which are directed toward the autonomy and religious authenticity (Głód 2006; Walesa 2006).

Secondly, religion is an integral and important component of the Polish culture. Religious practices are commonly used by Polish people (even young people), who are mainly Catholics (Święs 2006). But the question remains whether religion manifests itself in a similar way in both cultures? Are religious coping strategies similar across cultures and in different age groups (American adults versus Polish adolescents)? To answer these questions, the process of cultural adaptation of the RCOPE has been conducted with a view to achieving cultural equivalence between the source and target versions of the questionnaire.

The aim of this study is to present the process of the cultural adaptation of the RCOPE for Polish adolescents. Next, some results of the study using the Polish version of the RCOPE are presented.

\section{Cultural Adaptation}

With the permission of Kenneth I. Pargament, ${ }^{1}$ the Polish version of the RCOPE was adapted in 2008 by Professor Leszek Szewczyk and Elżbieta Talik (Weinmuller), PhD, at the Department of Clinical Psychology of Children and Adolescent at the John Paul II Catholic University of Lublin. The Polish version was developed according to guidelines for cross-cultural adaptation recommended by International Test Commission (ITC) (Hambleton 2001) which include issues of structural and measurement equivalence. Structural equivalence (also termed conceptual or construct equivalence) is concerned with the extent to which the meaning and dimensional structure of a psychological construct are identical across cultural groups. Measurement equivalence is concerned with the extent to which both the item content and psychometric properties (i.e. validity and reliability) of the instrument are similar across cultures. Linguistic (or semantic) equivalence represents a special case of measurement equivalence in which the original instrument is translated into another language.

\section{Structural Equivalence}

Firstly, the construct equivalence of the instruments was assessed. We referred to the basic perspectives for cross-cultural studies which have been called the "emic-etic paradigm"

\footnotetext{
1 The permission obtained by e-mail on 7 April, 2004.
} 
(Brislin 1976). The emic perspective involves the evaluation of specific phenomena from within the culture and its context. The etic perspective, on the other hand, is directed at identifying and comparing common phenomena across different cultural contexts. Theoretical construct that is measured by the RCOPE is religious coping strategies. Religion is conceptualized as systems of significance that are grounded in beliefs about the sacred (individual aspect) and is realized within broader religious context e.g. in a congregation (institutional aspect) (Pargament 1997). Both individual and institutional aspects of religion are present in Polish psychology of religion (see: Chlewiński 1989; Głaz 2004; Prężyna 1981; Szymołon 2006). The main functions of religion identified by Pargament et al. (2000) are consistent across both cultures: religion plays a key role in searching for meaning, sense of life (Chlewiński 1991; Kozielecki 1991; Mariański 1990; Socha 2000a); religion offers many ways to achieve control (Chlewiński 1982a, b; Kozielecki 1991). Religion also can be a source of comfort and closeness to God (see: Kubacka-Jasiecka et al. 1996; Grzymała-Moszczyńska 1996) and to other people (Chlewiński 1989; Prężyna 1981). Religion can have some therapeutic function: it releases one from feeling guilty (Chlewiński 1982a, b; Grzymała-Moszczyńska 1996) or even prevents pathology (Kozielecki 1991). In the Polish literature of the subject, there are other functions (emic aspect), for instance religion is the basis of a value-system (Prężyna 1981; Mariański 1990) or can help people in personality development (Grzymała-Moszczyńska 1996; KubackaJasiecka et al. 1996).

There are many similarities in behaviors associated with the theoretical construct across both cultures, such as questioning of God's power, punishing God reappraisal, collaboration with God in problem solving, pleading for God's intercession (see: Wandrasz 2006). It seems that only one religious coping strategy is more specific for the American culture than Polish (emic aspect), namely Marking Religious Boundaries, as the Roman-Catholic denomination is widespread in Poland. Therefore, there is no need to stay away from false religious teaching (item 66) or avoiding people who aren't of my faith (item 87).

To summarize this point, it seems that construct equivalence has been positively verified. The behaviors associated with the theoretical construct are in many ways similar in the source and target culture. There are some etic aspects regarding the definition and function of religion. There are also some emic aspects that relate to a few functions and manifestations of religion.

The next point of the article concerns measurement equivalence and it starts with linguistic equivalence. Therefore, psychometric adaptation of the RCOPE is described.

\section{Measurement Equivalence}

At the beginning of this stage, a linguistic adaptation was conducted, which is commonly treated as a special case of measurement equivalence (Bartram 2009).

\section{Linguistic (Semantic) Equivalence}

The first step involved translation of the original version of the RCOPE into Polish. A committee translation procedure was conducted, consisting of four independent translators and psychologists with advanced English. They knew the target population (adolescents) had a knowledge of the construct being assessed (religious coping) and had some knowledge of test development. Next, the four translations were reviewed by additional committee of experienced clinicians and researchers from the clinical psychology seminar (12 persons). They assessed each item according to an appropriate scale. Interjudge 
reliability at the level of $50 \%$ was enough to choose the ultimate translation of each item. We decided not to use the back-translation procedure which is widely criticized as not sufficient to obtain cultural equivalency of the instrument (Byrne et al. 2009; Geisinger 1994; Gregoire and Hambleton 2009; Hambleton 2001; Vijver and Hambleton 1996). After the first version of the translation was produced, it was pretested with a group of 30 persons that represented the target population, namely students of a secondary school in Lublin. We included an interview with the pilot participants to find out their reactions to the instrument instructions, items and response categories. After the initial pilot data were collected, the team members from the clinical seminar met again to consider any necessary changes. The items found to present difficulties in comprehension were modified to remove any limitations that were noticed.

To sum up, in our attempt to obtain semantic equivalence some words and phrases were changed according to the feedback from both groups (experts and adolescents). We tried to find balance between a literal translation and a culturally specific translation (Hambleton 2001); therefore, we tried to place emphasis on the translation of the intent of an item rather than on literal translation. The main changes concerned the passive tense that is prevalent in English but much less common in Polish; therefore, we used much more of the active tense constructions in the target translation. In two cases, the word "God" was added (to "spiritual force" in item 72 and to "higher power" in item 95). It was added to make clear the sense of Christian roots of these items. To avoid negative connotations of the word "clergy", we changed it into "priests". The word "congregation" was replaced with "church", which is more relevant in the Polish religious context.

Some alterations were made according to the instruction. We did not go for a literal translation and instead paraphrased part of the text. People responded to the items on the same 4 point Likert scale rating, ranging from the same point (from 0 to 3 ), but we retained only one answer option (leaving 'how frequently' and deleting 'how much'). This change was made according to both an expert and adolescent opinion who regarded the remaining two options misleading. The same layout and format of the instrument was maintained in its original version.

\section{Psychometric Equivalence}

At this stage, a psychometric adaptation of the questionnaire was conducted together with initial validation investigation. The validation was done on a sample of 400 secondary school students: 245 girls (61. 3\%) and 155 boys (38. 8\%). The average age of the participants was 18.23 (17-20). A vast majority of the respondents declared to be believers $(76.3 \%)$ and practicing church-goers $(61 \%)$. All subjects declared to be Roman Catholics. It is necessarily to emphasize that the sample was relatively homogenous, as most participants were young Catholics. This is so because the majority of believers in Poland are Catholics (above 90\%). Given such a narrow faith composition of the sample, the generalizability of the present results to different ages and other religious groups is limited.

We started off by conducting a number of item analyses to evaluate response biases, such as frequency distributions and evaluation of skewness and kurtosis of the items. Principal psychometric adaptation was done using an exploratory factor analysis with principal components extraction and oblique rotation (delta $=0$ ). We tried to repeat the author's steps of psychometric analysis, described in detail elsewhere (see: Pargament et al. 2000). In the beginning, our team repeated all of their steps, but none of the obtained models was 
Table 1 Eigenvalues of items and total variance explained

\begin{tabular}{llll}
\hline \multirow{2}{*}{ Factor } & \multicolumn{2}{l}{ Total variance explained } & \\
\cline { 2 - 4 } & Eigenvalues & \% cumulative \\
\cline { 2 - 4 } & General & $\%$ of variance & 44.59 \\
1 & 7.13 & 44.59 & 59.14 \\
\hline
\end{tabular}

satisfied because of many crossloadings of items and overfactored solutions. ${ }^{2}$ Therefore, the next set of analyses was slightly modified. Those results are presented below in details.

Hierarchical factor analysis was conducted. All of the 105 items were entered into an exploratory factor analysis with principal components extraction and oblique rotation $($ delta $=0)$ with the solution constrained to generate only two factors. ${ }^{3}$ The relevance of the model was confirmed by Kaiser-Meyer-Olkin Measure of Sampling Adequacy $(K M O=0.92)$ and Bartlett's Test of Sphericity $\left(\chi^{2}=4,331.01 ; P<0.001\right)$. These twofactor solutions accounted for $59.13 \%$ of the variance. Each of the factors fulfills KaiserGuttman criterion (eigenvalues greater than 1) (see Table 1).

As suggested by Pargament et al. (2000), items with factor loadings of more than 0.30 were accepted. An examination of the pattern matrix revealed two items that had factor loading of less than 0.30 and four crossloadings of items. These items were dropped accordingly. Finally, after another factor analysis, the first factor consisted of 65 items, and the second was formed from 34 items.

A total of 65 items from the first factor were entered into an exploratory factor. The relevance of the model was confirmed by Kaiser-Meyer-Olkin Measure of Sampling Adequacy $(K M O=0.97)$ and Bartlett's Test of Sphericity $\left(\chi^{2}=17,937.42 ; P<0.001\right)$. Nine factors were obtained, which accounted for $62.84 \%$ of the variance. Items were included in a factor if their value was greater than 0.40 . An examination of the pattern matrix revealed fifteen crossloadings of items. These items were dropped, and the remaining ones were entered into another factor analysis. After a fourth factor analysis, the pure nine factor structure was obtained, without croosloadings of items. These nine factors solutions accounted for $65.19 \%$ of the variance (Table 2). An examination of the item content revealed that these factors set up positive religious strategies scales.

The same analysis referred to 34 items from the second main factor. Again, the relevance of the model was confirmed by Kaiser-Meyer-Olkin Measure of Sampling Adequacy $(K M O=0.90)$ and Bartlett's Test of Sphericity $\left(\chi^{2}=17,937.42 ; P<0.001\right)$. Seven factors were obtained which accounted for $61.77 \%$ of the variances. An examination of the pattern matrix revealed only two items with eigenvalues less than 0.40 . These items were dropped, and the rest was entered into another factor analysis. The pure seven factor structure was obtained after a third factor analysis. This solution accounted for $63.39 \%$ of the variance. (Table 3). An examination of the item content revealed that these factors set up negative religious strategies scales.

\footnotetext{
2 This part of analysis is described in details in unpublished doctoral thesis by Talik (2008). Religious and non-religious coping strategies and the sense of controllability of stressful situation among adolescents. Lublin: KUL.

${ }^{3}$ It was hypothesized that most of the items from the different subscales could be classified as either positive or negative religious strategies.
} 
Table 2 Eigenvalues of items and total variance explained of positive factors

\begin{tabular}{llll}
\hline \multirow{4}{*}{ Factor } & \multicolumn{2}{l}{ Total variance explained } \\
\cline { 2 - 4 } & \multicolumn{2}{l}{ Eigenvalues } & \% cumulative \\
\cline { 2 - 4 } & General & \% of variance & 38.07 \\
\hline 1 & 18.27 & 38.07 & 44.31 \\
2 & 2.30 & 6.24 & 48.22 \\
3 & 1.88 & 3.91 & 51.67 \\
5 & 1.66 & 3.45 & 54.97 \\
6 & 1.58 & 3.30 & 57.91 \\
7 & 1.41 & 2.93 & 60.50 \\
8 & 1.25 & 2.59 & 62.96 \\
9 & 1.18 & 2.47 & 65.19 \\
\hline
\end{tabular}

\begin{tabular}{llll}
\hline \multirow{4}{*}{ Factor } & \multicolumn{3}{l}{ Total variance explained } \\
\cline { 2 - 4 } & \multicolumn{2}{l}{ Eigenvalues } \\
\cline { 2 - 4 } & General & \% of variance & \% cumulative \\
\hline 1 & 8.33 & 26.02 & 26.02 \\
2 & 4.08 & 12.75 & 38.77 \\
3 & 2.26 & 7.05 & 45.82 \\
4 & 1.83 & 5.72 & 51.54 \\
5 & 1.47 & 4.59 & 56.13 \\
6 & 1.30 & 4.05 & 60.19 \\
7 & 1.03 & 3.20 & 63.39 \\
\hline
\end{tabular}

Table 3 Eigenvalues of items and total variance explained of negative factors

These results were compared with the original version of the RCOPE: 6 factors were retained in their original form. The major difference concerned factor number 8 that was formed by combining two factors: Marking Religious Boundaries and Religious Purification. The next difference concerned factor number 6. Pleading for Direct Intercession, which in the Polish version is treated as a positive religious strategy while in the original is included among the negative strategies. One factor, Spiritual Connection, has been missing in the Polish version.

In addition, a discrimination analysis of each item was estimated with Phi correlation coefficient. All correlations are significant $(P<0.001)$, high (from 0.71$)$ and very high (from 0.91).

In summary, the final Polish version of the RCOPE consists of 105 items from 16 scales, positive (9) and negative (7) religious strategies, but only 85 items are diagnostic.

Positive religious strategies are as follows:

1. Life Transformation (LT)_-looking to religion for a radical change in life; seeking a new direction for life (7 items);

2. Active Religious Surrender (ARS) — voluntarily giving up control to God in coping (5 items);

3. Seeking Support from Priests/Members (SSM)—searching for comfort, pleading and spiritual support from priests or church members (5 items); 
4. Religious Focus (RF)—engaging in religious activities to shift the focus from the stressor;

5. Collaborative Religious Coping (CRC)—partnership with God in problem solving and redefining the stressor through religion as benevolent (5 items);

6. Pleading for direct Intercession (PDI) - pleading to God for a miracle or divine intercession (4 items);

7. Spiritual Support (SS)—seeking and giving spiritual support to others (4 items);

8. Religious Practices (RP)—active practicing and faithfulness to religious principles (8 items);

9. Benevolent Religious Reappraisal (BRR)—redefining the stressor through religion as benevolent and potentially beneficial (8 items).

Negative religious are as follows:

10. Punishing God Reappraisal (PGR) - redefining the stressor as a punishment from God for the individual's sins (5 items);

11. Self-directing Religious Coping (SRC)—coping without God's help (5 items);

12. Demonic Reappraisal (DR)—redefining the stressor as the act of the Devil (4 items);

13. Passive Religious Deferral (PRD)—passive waiting for God to control the situation and solve the problem (5 items);

14. Spiritual Discontent (SD) - expressing dissatisfaction and anger with God's relationship to the individual in a stressful situation (7 items);

15. Reappraisal of God's Power (RGP)—questioning God's Power to influence the stressful situation (4 items);

16. Religious Discontent (RD) - dissatisfaction with congregation members and questioning Church' s teaching (2 items).

People responded to the items on a 4-point Likert scale rating, ranging from 0 "not at all" to 3 "a great deal". They assessed the degree to which they made use of various religious coping strategies (positive and negative). The scores were calculated according to 16 scales.

The next step of cultural adaptation process was to assess psychometric properties of the Polish version of the RCOPE including its reliability and validity.

Firstly, descriptive statistic for each scale was evaluated (Table 4).

The results indicated higher means and greater variance for positive religious coping strategies than negative ones, which is more of a general tendency (see: Pargament et al. 2000). In comparison with the original RCOPE (Pargament et al. 2000) means in the Polish study are higher for most of the scales, except for three scales with means higher for the American than Polish population, respectively: Self-Directing Religious Coping $(M=1.77 / 1.11)$, Reappraisal of God's Power $(M=0.98 / 0.87)$ and Benevolent Religious Reappraisal $(M=1.52 / 1.26)$,

Intercorrelations of Scales

Tables 5 and 6 present intercorrelations of dimensions relating to positive (Table 5) and negative (Table 6) religious coping strategies.

Correlations between positive religious strategies ranged between 0.43 and 0.86 , negative - between-0.11 and 0.78. All of them are significant $(P<0.01$ and 0.05$)$ except one pair: Passive Religious Deferral and Religious Discontent. 
Table 4 Descriptive statistic in the Polish version of the RCOPE

\begin{tabular}{llrlllllllr}
\hline No & Scale & Items & Min & Max & $M$ & Stand. Error & SD & Variance & Skewness & Kurtosis \\
\hline 1 & LT & 7 & 0 & 3 & 1.15 & 0.04 & 0.75 & 0.56 & 0.41 & -0.42 \\
2 & ARS & 5 & 0 & 3 & 1.31 & 0.04 & 0.74 & 0.54 & 0.21 & -0.28 \\
3 & SSM & 5 & 0 & 3 & 0.77 & 0.03 & 0.68 & 0.47 & 0.83 & 0.04 \\
4 & RF & 5 & 0 & 3 & 0.91 & 0.03 & 0.66 & 0.44 & 0.64 & 0.01 \\
5 & CRC & 5 & 0 & 3 & 1.24 & 0.03 & 0.67 & 0.45 & 0.20 & -0.38 \\
6 & PDI & 4 & 0 & 3 & 1.46 & 0.03 & 0.69 & 0.48 & 0.15 & -0.40 \\
7 & SS & 5 & 0 & 3 & 1.05 & 0.03 & 0.66 & 0.44 & 0.34 & -0.38 \\
8 & RP & 8 & 0 & 3 & 1.47 & 0.03 & 0.64 & 0.41 & -0.04 & -0.25 \\
9 & BRR & 4 & 0 & 3 & 1.26 & 0.04 & 0.73 & 0.53 & 0.35 & -0.37 \\
Positive strategies (PS) & 48 & 0 & 2.73 & 1.19 & 0.03 & 0.54 & 0.29 & 0.25 & -0.03 \\
10 & PGR & 5 & 0 & 3 & 1.13 & 0.03 & 0.69 & 0.48 & 0.43 & -0.13 \\
11 & SRC & 5 & 0 & 3 & 1.11 & 0.03 & 0.66 & 0.43 & 0.43 & -0.07 \\
12 & DR & 4 & 0 & 3 & 0.66 & 0.03 & 0.69 & 0.48 & 0.89 & 0.20 \\
13 & PRD & 5 & 0 & 3 & 0.60 & 0.03 & 0.61 & 0.37 & 1.06 & 0.70 \\
14 & SD & 7 & 0 & 3 & 0.76 & 0.03 & 0.57 & 0.33 & 0.80 & 0.48 \\
15 & RGP & 4 & 0 & 2.5 & 0.87 & 0.03 & 0.61 & 0.37 & 0.47 & -0.52 \\
16 & RD & 2 & 0 & 3 & 0.99 & 0.04 & 0.72 & 0.51 & 0.50 & -0.27 \\
Negative & strategies (NS) & 32 & 0 & 2.16 & 0.86 & 0.02 & 0.40 & 0.16 & 0.60 & -0.09 \\
\hline
\end{tabular}

Table 5 Intercorrelations of scales measuring positive religious strategies ( $r h o$-Spearman coefficient)

\begin{tabular}{|c|c|c|c|c|c|c|c|c|c|c|}
\hline \multirow[t]{2}{*}{ Scale } & \multicolumn{10}{|c|}{ Intercorrelations of scales } \\
\hline & (1) & (2) & (3) & (4) & (5) & (6) & (7) & (8) & (9) & (10) \\
\hline LT (1) & - & & & & & & & & & \\
\hline ARS (2) & $0.58 * *$ & - & & & & & & & & \\
\hline SSM (3) & $0.65 * *$ & $0.48^{* *}$ & - & & & & & & & \\
\hline RF (4) & $0.73 * *$ & $0.56^{* *}$ & $0.61 * *$ & - & & & & & & \\
\hline CRC (5) & $0.72 * *$ & $0.70^{* *}$ & $0.58 * *$ & $0.72 * *$ & - & & & & & \\
\hline PDI (6) & $0.68 * *$ & $0.58^{* *}$ & $0.49 * *$ & $0.69 * *$ & $0.68 * *$ & - & & & & \\
\hline SS (7) & $0.63 * *$ & $0.43 * *$ & $0.62 * *$ & $0.55^{* *}$ & $0.52 * *$ & $0.49 * *$ & - & & & \\
\hline RP (8) & $0.77 * *$ & $0.59 * *$ & $0.61 * *$ & $0.66 * *$ & $0.69 * *$ & $0.63 * *$ & $0.59 * *$ & - & & \\
\hline BRR (9) & $0.73^{* *}$ & $0.59 * *$ & $0.54 * *$ & $0.68^{* *}$ & $0.75 * *$ & $0.59^{* *}$ & $0.58 * *$ & $0.69 * *$ & - & \\
\hline Positive strategies (10) & $0.89 * *$ & $0.76^{* *}$ & $0.73 * *$ & $0.83 * *$ & $0.86 * *$ & $0.78 * *$ & $0.72 * *$ & $0.87 * *$ & $0.83 * *$ & - \\
\hline
\end{tabular}

** Correlation is significant at the 0.01 level (two tailed)

\section{Reliability}

Cronbach's alpha coefficient estimates were calculated to assess reliability of the Polish RCOPE (Table 7).

Reliability estimates are generally high and very high, indicating good internal consistency. Only two scales (15 and 16) have moderate reliability estimates. Comparing it 
Table 6 Intercorrelations of scales measuring negative religious strategies ( $r h o$-Spearman coefficient)

\begin{tabular}{|c|c|c|c|c|c|c|c|c|}
\hline \multirow[t]{2}{*}{ Scale } & \multicolumn{8}{|c|}{ Intercorrelations of scales } \\
\hline & (1) & (2) & (3) & (4) & (5) & (6) & (7) & (8) \\
\hline PGR (1) & - & & & & & & & \\
\hline SRC (2) & $-0.11 *$ & - & & & & & & \\
\hline DR (3) & $0.52 * *$ & $-0.14 * *$ & - & & & & & \\
\hline PRD (4) & $0.37 * *$ & $-0.31 * *$ & $0.40 * *$ & - & & & & \\
\hline SD (5) & $0.53 * *$ & $0.12 *$ & $0.40 * *$ & $0.27 * *$ & - & & & \\
\hline RGP (6) & $0.31 * *$ & $0.26 * *$ & $0.25 * *$ & $0.15^{* *}$ & $0.50 * *$ & - & & \\
\hline $\mathrm{RD}(7)$ & $0.26^{* *}$ & $0.23 * *$ & $0.19 * *$ & 0.03 & $0.44 * *$ & $0.25 * *$ & - & \\
\hline Negative strategies (8) & $0.68 * *$ & $0.39 * *$ & $0.55 * *$ & $0.36 * *$ & $0.78 * *$ & $0.63 * *$ & $0.54 * *$ & - \\
\hline
\end{tabular}

* Correlation is significant at the 0.05 level (2-tailed)

** Correlation is significant at the 0.01 level (2-tailed)

Table 7 Internal consistency of the Polish version of the RCOPE

\begin{tabular}{lllr}
\hline Factor & Scale & $\alpha$ Cronbacha & Items \\
\hline 1 & LT & 0.92 & 7 \\
2 & ARS & 0.89 & 5 \\
3 & SSM & 0.84 & 5 \\
4 & RF & 0.85 & 5 \\
5 & CRC & 0.86 & 5 \\
6 & PDI & 0.78 & 4 \\
7 & SS & 0.82 & 5 \\
8 & RP & 0.86 & 8 \\
9 & BRR & 0.85 & 4 \\
Positive strategies & & 0.91 & 48 \\
10 & PGR & 0.86 & 5 \\
11 & SRC & 0.83 & 5 \\
12 & DR & 0.90 & 4 \\
13 & PRD & 0.85 & 5 \\
14 & SD & 0.84 & 7 \\
15 & RGP & 0.66 & 4 \\
16 & RD & 0.62 & 2 \\
Negative strategies & & 0.71 & \\
\hline & & & 52 \\
\hline
\end{tabular}

with the reliability of the original version, we could state that alpha coefficient estimates are very similar: in the original from 0.61 (Marking Religious Boundaries) to 0.94 (Religious Direction/Conversion).

\section{Validity}

There was a moderate but statistically significant correlation $(r=0.59 ; P<0.01)$ of the Polish RCOPE with CKI Scale by W. Prężyna, which was test criterion. This scale assesses 
the intensity of a religious attitude. Further psychometric evaluation that is recommended includes gathering new data to establish new norms as well as assessing the stability of the instrument with test-retest reliability.

\section{Applications of the Adolescents Religious Coping Questionnaire}

The Adolescents Religious Coping Questionnaire is designed to assess positive and negative religious coping strategies of those adolescents who deal with stressful situations. Reliability and validity of the method are satisfied; therefore, the questionnaire could be used in individual psychological counseling and pastoral youth service as well as in scientific research. Due to the lowest reliability coefficient concerning two scales (Reappraisal of God's Power and Religious Discontent), the results from these scales should be treated carefully.

\section{The Adolescents Religious Coping Questionnaire in Research to Date}

The following example study concerns the relationship between religious coping strategies and selected personal resources: the sense of controllability of the stressful situation and the self-efficacy in adolescents. The sense of controllability means subjective assessment to what extent the stressful situation (its source and results) depends on person (Heszen-Niejodek 2000). The self-efficacy has been defined as a belief that one has the capabilities to execute the courses of actions required to manage prospective situations (Bandura 1993). A total of 451 adolescents were investigated (278 girls and 173 boys), aged 16-18, with Sense of Controllability Scale and Survey by E. Talik (2008) and The Self-Efficacy Scale by Z. Juczyński. The participants were predominantly Catholic (98\%).

To test whether there are any significant differences in terms of religious coping strategies between persons with low (1) versus high (3) level of both personal resources, a contrast analysis was conducted. The results regarding the sense of controllability are presented in Table 8 (only significant differences are presented).

The results indicated that adolescents with a low level of the sense of controllability more frequently choose one positive religious strategy-Religious Focus (RF) and one negative religious strategy-Passive Religious Deferral (PRD).

The results regarding self-efficacy are presented in Table 9.

Adolescents with a high level of self-efficacy more frequently choose the following positive religious strategies: Active Religious Surrender, Collaborative Religious Coping, Spiritual Support, and Benevolent Religious Reappraisal. Adolescents with a low level of self-efficacy more frequently choose the following negative religious strategies: Punishing God Reappraisal, Passive Religious Deferral, and Spiritual Discontent.

Table 8 Significant differences regarding religious coping strategies between adolescents with low (1) and high (3) level of the sense of controllability

\begin{tabular}{lllllllll}
\hline Religious coping strategies & $t$ & df & $P<$ & Groups & $N$ & $M$ & SD & Stand. error \\
\hline RF & -1.97 & 448 & 0.05 & 1 & 162 & 3.67 & 3.49 & 0.27 \\
& & & & 3 & 137 & 2.92 & 3.03 & 0.26 \\
PRD & -2.07 & \multirow{2}{*}{296.634} & 0.05 & 1 & 162 & 2.20 & 2.69 & 0.21 \\
& & & & 3 & 137 & 1.61 & 2.20 & 0.19 \\
\hline
\end{tabular}


Table 9 Significant differences regarding religious coping strategies between adolescents with low (1) and high (3) level of the self-efficacy

\begin{tabular}{lllllllll}
\hline $\begin{array}{l}\text { Religious } \\
\text { coping strategies }\end{array}$ & $t$ & df & & $P<$ & Groups & $N$ & $M$ & SD \\
\hline ARS & 2.79 & 448 & 0.01 & 1 & 4.85 & 4.35 & 0.52 \\
& & & & & 3 & 6.53 & 4.88 & 0.34 \\
CRC & 2.45 & 448 & 0.05 & 1 & 4.31 & 3.57 & 0.42 \\
& & & & & 3 & 5.55 & 3.98 & 0.28 \\
SS & 2.01 & 448 & 0.05 & 1 & 3.34 & 3.23 & 0.38 \\
& & & & & 3 & 4.32 & 3.80 & 0.26 \\
PGR & 2.49 & 275 & 0.01 & 1 & 461 & 3.64 & 0.43 \\
& & & & & 3 & 3.41 & 3.44 & 0.24 \\
PRD & 3.01 & 101.183 & 0.01 & 1 & 2.44 & 2.75 & 0.33 \\
& & & & & 3 & 1.35 & 2.15 & 0.15 \\
SD & 1.97 & 105.751 & 0.05 & 1 & 4.11 & 4.12 & 0.49 \\
& & & & 3 & 3.04 & 3.45 & 0.24 \\
\hline
\end{tabular}

\section{Discussion}

There are significant differences according religious coping strategies between adolescents with low and high levels of selected personal resources (the sense of controllability of the stressful situation and the self-efficacy).

Adolescents who have perceived their stressful situation as being beyond their control more frequently have been engaged in religious activities to shift the focus from the stressor and more often have passively waited for God to control the situation and solve the problem. They have manifested an avoiding attitude, which is typical for uncontrolled situations and, what is more, such avoidance could be more effective in situations which are beyond personal control, at least in a short perspective of time (see: Endler et al. 2000; Hagger and Orbell 2003; Heszen-Niejodek 1996). But when religion serves only this one negative purpose, there is a chance that it would become a form of psychopathology (cf. Belzen 1996; Beit-Hallahmi,1996; Chlewiński 1991). Adolescents have omitted positive functions of religion such as meaning, intimacy or life transformation (Pargament et al. 2000). The question is whether religion is not attractive enough for the young. Or perhaps their problems are not difficult enough. Religion specifically compels for border situations (Pargament 1997).

Regarding the second resource, adolescents with a low level of self-efficacy more often have perceived the stressful situation as a punishment from God for one's sins or they just have expressed dissatisfaction and anger with God and have passively waited for God to solve their problem. If individuals badly assess their capabilities, they concentrate on the obstacles (Bandura 1993) and this favors passivity, also religious one (Pargament 1990a). If individuals assess low their self-efficacy, it is easy to relieve themselves of the responsibility for the problem and transfer it to another person, be it God or Devil. It could be a method of protection of one's self-esteem (Spilka et al. 1985). Adolescents who have perceived themselves as less effective more frequently express their dissatisfaction with God-the low level of self-efficacy is connected with negative emotions (Bandura 1993; Bandura and Locke 2003).

On the contrary, adolescents with high level of self-efficacy have been actively engaged in resolving a stressful situation, with God's help or by actively surrendering control to 
God in coping. They also have tried to redefine the stressor as benevolent and potentially beneficial and found spiritual support. The similar result has been obtained by Pargament et al. (2000, 2004a, b).

\section{Conclusions}

The article has presented the process of translation and cultural adaptation of Kenneth I. Pargament's RCOPE Questionnaire. This process was carried out in order to assess the degree of cultural equivalence of religious coping strategies between the American and Polish cultures. It seems that the final Polish version of the RCOPE is more of a paraphrase than adaptation of the original RCOPE. The factor structure differs from the original: just 6 factors have been retained in their original form. The remaining factors consisted of items from more than one factor. Additionally, in the Polish version, two factors of the higher order have been generated (positive and negative religious coping strategies) which is largely consistent with many other studies (e.g. Pargament et al. 2004a). The theoretical construct, i.e. religious coping strategies, was confirmed in the target culture. Religion for Polish people serves the same purposes, but it manifests itself in a different way. Thus, we can conclude that those two general dimensions are common for both cultures, but more concrete signs of positive and negative religious coping are, to a large extent, specific for the source and target culture with the exception of strategies as follows: Active Religious Surrender, Seeking Support from Clergy/Members, Religious Focus, Punishing God Reappraisal, Self-Directing Religious Coping, and Passive Religious Deferral. The Polish version of the RCOPE exhibits psychometric properties equivalent to those of the original version. They are fulfilled; therefore, the Polish version of the RCOPE can be used for comparative youth groups, who deal with different stressful situations.

Open Access This article is distributed under the terms of the Creative Commons Attribution Noncommercial License which permits any noncommercial use, distribution, and reproduction in any medium, provided the original author(s) and source are credited.

\section{References}

Abu Raiya, H., Pargament, K. I., Mahoney, A., \& Stein, C. (2008). A psychological measure of Islamic religiousness (PMIR): Development and evidence for reliability and validity. International Journal for the Psychology of Religion, 18, 291-315.

Amer, M. M., Hovey, J. D., Fox, C. M., \& Rezcallah, A. (2008). Initial development of the brief Arab religious coping scale (BARCS). Journal of Muslim Mental Health, 3(1), 69-88.

Ano, G. G., \& Vasconcelles, E. B. (2005). Religious coping and psychological adjustment to stress: A metaanalysis. Journal of Clinical Psychology, 61(4), 461-480.

Bandura, A. (1993). Perceived self-efficacy in cognitive development and functioning. Educational Psychologist, 28, 117-148.

Bandura, A., \& Locke, E. A. (2003). Negative self-efficacy and goal effects revisited. Journal of Applied Psychology, 88(1), 87-99.

Bartram, D. (2009). The international test commission guidelines on computer-based and internet-delivered testing. Industrial and Organizational Psychology: Perspectives on Science and Practice, 2(1), 11-13.

Beit-Hallahmi, B. (1996). Religion as psychopatology: Exploring a metaphor. [W:] H.Grzymała-Moszczyńska \& B. Beit-Hallahmi (red.), Religion, psychopatology and coping (pp. 71-85). AmsterdamAtlanta: Rodopi.

Belzen, J. A. (1996). Methodological perspectives on psychopatology and religion: A historical review. [W:] H.Grzymała-Moszczyńska \& B.Beit-Hallahmi (red.), Religion, psychopatology and coping (s. 23-34). Amsterdam-Atlanta: Rodopi. 
Benore, E., Pargament, K. I., \& Pendleton, S. (2008). An initial examination of religious coping in children with asthma. International Journal for the Psychology of Religion, 18(4), 267-290.

Bjorck, J. P., \& Thurman, J. W. (2007). Negative life events, patterns of positive and negative religious coping, and psychological functioning. Journal for the Scientific Study of Religion, 46(2), 159-167.

Brislin, R. W. (1976). Comparative research methodology: Cross-cultural studies. International Journal of Psychology, 11(3), 215-229.

Byrne, B. M., Leong, F. T., Hambleton, R. K., Oakland, T., Vijver, F. T., Cheung, F. M., et al. (2009). A critical analysis of cross-cultural research and testing practices: Implications for improved education and training in psychology. Training and Education in Professional Psychology, 3(2), 94-105.

Carleton, R., Esparza, P., Thaxter, P., \& Grant, K. (2008). Stress, religious coping resources, and depressive symptoms in an urban adolescent sample. Journal for the Scientific Study of Religion, 47(1), 113-121.

Chlewiński, Z. (1982a). Rola religii w funkcjonowaniu osobowości. [W:] Z. Chlewiński (red.), Psychologia religii (s. 61-76). Lublin: RW KUL.

Chlewiński, Z. (1982b). Rola religii w funkcjonowaniu osobowości. [W:] Z. Chlewiński (red.), Psychologia religii (s. 61-76). Lublin: RW KUL.

Chlewiński, Z. (1989). Religijność dojrzała. [W:] Z. Chlewiński (red.), Wybrane zagadnienia z psychologii pastoralnej (s. 9-3). Lublin: RW KUL.

Chlewiński, Z. (1991). Dojrzatoś́. Osobowość, sumienie, religijność. Poznań:W drodze.

Cigrang, J. A., Hryshko-Mullen, A., \& Peterson, A. L. (2003). Spontaneous reports of religious coping by patients with chronic physical illness. Journal of Clinical Psychology in Medical Settings, 10(3), 133-137.

Conners, N. A., Whiteside-Mansell, L., \& Sherman, A. C. (2006). Dimensions of religious involvement and mental health outcomes among alcohol- and drug-dependent women. Alcoholism Treatment Quarterly, 24(1-2), 89-108.

Cotton, S., Puchalski, C. M., \& Sherman, S. N. (2006). Spirituality and religion in patients with HIV/AIDS. Journal of General Internal Medicine, 21(5), 5-13.

Dew, R. E., Daniel, S. S., Goldston, D. B., McCall, W. V., Kuchibhatla, M., Schleifer, C., et al. (2010). A prospective study of religion/spirituality and depressive symptoms among adolescent psychiatric patients. Journal of Affective Disorders, 120(1-3), 149-157.

Dunn, K. S., \& Horgas, A. L. (2004). Religious and nonreligious coping in older adults experiencing chronic pain. Pain Management Nursing, 5(1), 19-28.

Endler, N. S., Macrodimitris, S. D., \& Kocovski, N. L. (2000). Controllability in cognitive and interpersonal tasks: Is control good for you? Personality and Individual Differences, 29(5), 951-962.

Frazier, P., Tashiro, T., \& Berman, M. (2004). Correlates of levels and patterns of positive life changes following sexual assault. Journal of Consulting and Clinical Psychology, 72(1), 19-30.

Geisinger, K. F. (1994). Cross-cultural normative assessment: Translation and adaptation issues influencing the normative interpretation of assessment instruments. Psychological Assessment, 6(4), 304-312.

Głaz, S. (2004). Doświadczenie religijne a osobowosć. Kraków: WAM.

Głód, F. (2006). Kryzysy religijne. [W:] S. Głaz (red.), Podstawowe zagadnienia psychologii religii (s. 179-200). Kraków: Wydawnictwo WAM.

Gregoire, J., \& Hambleton, R. K. (2009). Advances in test adaptation research: A special issue. International Journal of Testing, 9(2), 75-77.

Grzymała-Moszczyńska, H. (1996). Religion as transgression: Psychological mechanisms involved in religion and mental illness. W: H. Grzymała-Moszczyńska \& B. Beit-Hallahmi (ed.), Religion, psychopatology and coping (s.87-93). Amsterdam-Atlanta: Rodopi.

Hagger, M. S., \& Orbell, S. (2003). A meta-analytic review of the common-sense model of illness representations. Psychology and Health, 18(2), 141-184.

Hambleton, R. K. (2001). The next generation of the ITC test translation and adaptation guidelenes. European Journal of Psychological Assessment, 17(3), 164-172.

Harris, J. I., Erbes, C. R., Engdahl, B. E., Olson, R. H. A., Winskowski, A. M., \& McMahill, J. (2008). Christian religious functioning and trauma outcomes. Journal of Clinical Psychology, 64(1), 17-29.

Harrison, M. O., Koenig, H. G., Hays, J. C., Eme-Akwari, A. G., \& Pargament, K. I. (2001). The epidemiology of religious coping: A review of recent literature. International Review of Psychiatry, 13, 86-93.

Henderson, L. A. (2010). Religious coping and subjective well-being: African Americans' experiences of surviving Hurricane Katrina. Dissertation Abstracts International: Section B: The Sciences and Engineering, 70(10-B), 6552.

Heszen-Niejodek, I. (1996). Stres i radzenie sobie- główne kontrowersje. [W:] I. Heszen-Niejodek \& Z. Ratajczak (red.), Człowiek $w$ sytuacji stresu. Problemy teoretyczne i metodologiczne (s. 12-43). Katowice: Wydawnictwo Uniwersytetu Śląskiego. 
Heszen-Niejodek, I. (2000). Teoria stresu psychologicznego i radzenia sobie. [W:] J. Strelau (red.), Psychologia. Podręcznik akademicki (t. 3, s. 465-492). Gdańsk: GWP.

Huang, X.-Y., Hung, B.-J., Sun, F. K., Lin, J.-D., \& Chen, C.-C. (2009). The experiences of carers in Taiwanese culture who have long-term schizophrenia in their families: A phenomenological study. Journal of Psychiatric and Mental Health Nursing, 16(10), 874-883.

Huguelet, P., Mohr, S., \& Jung, V. (2007). Effect of religion on suicide attempts in outpatients with schizophrenia or schizo-affective disorders compared with inpatients with non-psychotic disorders. European Psychiatry, 22(3), 188-194.

Jacobson, C. J., Jr., Luckhaupt, S. E., Delaney, S., \& Tsevat, J. (2006). Religio-biography, coping, and meaning-making among persons with HIV/AIDS. Journal for the Scientific Study of Religion, 45(1), $39-56$.

Jarosz, M. (2003). Interpersonalne uwarunkowania religijności. Lublin: TN KUL.

Koenig, H., \& Cohen, H. (1992). Religious coping and depression among elderly, hospitalized medically ill men. American Journal of Psychiatry, 149(12), 8.

Kozielecki, J. (1991). Z Bogiem albo bez Boga. Psychologia religii: nowe spojrzenie. Warszawa: Wydawnictwo Naukowe PWN.

Kubacka-Jasiecka, D., Dorczak, R., \& Opoczyńska M. (1996). The role of religious values in functioning and mental health. W: H. Grzymała-Moszczyńska \& B. Beit-Hallahmi (eds.), Religion, psychopatology and coping (s. 235-243). Amsterdam-Atlanta: Rodopi.

Major, B., Richards, C., \& Cooper, M. L. (1998). Personal resilience, cognitive appraisals, and coping: An integrative model of adjustment to abortion. Journal of Personality and Social Psychology, 74(3), $735-752$.

Mariański, J. (1990). Religijna koncepcja sensu życia. Roczniki Nauk Społecznych, tom XVIII, zeszyt 1, 253-272.

Michael, S. T., Crowther, M. R., \& Schmid, B. (2003). Widowhood and spirituality: Coping responses to bereavement. Journal of Women and Aging, 15(2-3), 145-165.

Mohr, S., Gillieron, C., \& Borras, L. (2007). The assessment of spirituality and religiousness in schizophrenia. Journal of Nervous and Mental Disease, 195(3), 247-253.

Molock, S. D., Puri, R., Matlin, S., \& Barksdale, C. (2006). Relationship between religious coping and suicidal behaviors among African American adolescents. Journal of Black Psychology, 32(3), 366-389.

Nairn, R. C., \& Merluzzi, T. V. (2003). The role of religious coping in adjustment to cancer. PsychoOncology, 12(5), 428-441.

Pargament, K. I. (1990a). God help me (I): Religious coping efforts as predictors of the outcomes to signifficant negative life events. Amierican Journal of Community Psychology, 18(6), 793-824.

Pargament, K. I. (1990b). God help me (II): Toward a theoretical framework of coping for the psychology of religion. Research in the Social Scientific of Religion., 2, 195-224.

Pargament, K. I. (1997). The psychology of religion and coping. Theory, research, practice. New York, London: The Guilford Press.

Pargament, K. I., Koenig, H. G., \& Perez, L. M. (2000). The many methods of religious coping: Development and initial validation of the RCOPE. Journal of Clinical Psychology, 56(4), 519-544.

Pargament, K. I., Koenig, H. G., Tarakeshwar, N., \& Hahn, J. (2004a). Religious coping methods a as predictors of psychological, physical, and spiritual outcomes among medically ill elderly patients: A two-year longitudinal study. Journal of Health Psychology, 9, 713-730.

Pargament, K. I., McCarthy, S., \& Shah, P. (2004b). Religion and HIV: A review of the literature and clinical implications. Southern Medical Journal, 97(12), 1201-1207.

Pargament, K. I., Smith, B. W., Koenig, H. G., \& Perez, L. (1998). Patterns of positive and negative religious coping with major life stressors. Journal for the Scientific Study of Religion, 37(4), 711-725.

Pargament, K. I., Zinnbauer, B. J., \& Scott, A. B. (2003). Red flags and religious coping: Identifying some religious warning signs among people in crisis. Journal of Clinical Psychology, 59(12), 1335-1348.

Park, C. L., \& Fenster, J. R. (2004). Stress-related growth: Predictors of occurrence and correlates with psychological adjustment. Journal of Social and Clinical Psychology, 23(2), 195-215.

Pendleton, S. M., Cavalli, K. S., Pargament, K. I., \& Nasr, S. Z. (2002). Religious/spiritual coping in childhood cystic fibrosis: A qualitative study. Pediatrics, 109, 1-11.

Pieper, J. Z. T. (2004). Religious coping in highly religious psychiatric inpatients. Mental Health, Religion and Culture, 7(4), 349-363.

Pinnow, C. R. (2001). Adolescents in foster care, parental death and religious coping. Dissertation Abstracts International: Section B: The Sciences and Engineering, 62(5-B), 2497.

Prężyna, W. (1981). Funkcja postawy religijnej w osobowości cztowieka. Lublin: RW KUL. 
Rosmarin, D. H., Pargament, K. I., Krumrei, E. J., \& Flannelly, K. J. (2009). Religious coping among Jews: Development and initial validation of the JCOPE. Journal of Clinical Psychology, 65(7), 670-683.

Sherman, A. C., Simonton, S., Latif, U., Spohn, R., \& Tricot, G. (2005). Religious struggle and religious comfort in response to illness: Health outcomes among stem cell transplant patients. Journal of Behavioral Medicine, 28(4), 359-367.

Shortz, J. L., \& Worthington, E. L. (1994). Young adults' recall of religiosity, attributions, and coping in parental divorce. Journal for the Scientific Study of Religion, 33(2), 172-179.

Smith, B. W., Pargament, K. I., \& Brant, C. (2000). Noah revisited: Religious coping by church members and the impact of the 1993 Midwest flood. Journal of Community Psychology, 28(2), 169-186. Special issue: Spirituality, religion, and community psychology.

Socha, P. (1995). Religijny i niereligijny sposób radzenia sobie ze stresem bezrobocia. Rozważania wstępne. [W:] Z. Ratajczak (red.), Bezrobocie. Psychologiczne i społeczne koszty transformacji społecznej. Seria: Psychologiczne problemy człowieka w sytuacji pracy (t. 2(12), 21, 100-111). Katowice: Prace Naukowe UŚ.

Socha, P. (1997). Religijność a radzenie sobie w sytuacjach bezrobocia, samotności, alkoholizmu i narkomanii. Przeglad Religioznawczy, 2(184), 111-124.

Socha, P. (2000a). Psychologia rozwoju duchowego-zarys zagadnienia. [W:] P. Socha (red.), Duchowy rozwój cztowieka (s. 15-44). Kraków:Wydawnictwo Uniwersytetu Jagiellońskiego.

Socha P. (2000b). Religijne radzenie sobie z sytuacją bezrobocia. W: T. Doktór \& K. Franczak (red.), Postawy wobec religii. Psychologiczne uwarunkowania $i$ konsekwencje (s.139-160). Warszawa: Salezjański Instytut Wychowania Chrześcijańskiego.

Spilka, B., Shaver, P., \& Kirkpatrik, L. A. (1985). A general attribution theory for the psychology of religion. Journal for the Scientific Study of Religion, 24(1), 1-20.

Stoebe, M. (2004). Religion in coping with bereavement: Confidence of convictions or scientific scrutiny? International Journal for the Psychology of Religion, 14(1), 14-23.

Święs, K. (2006). Religijność współczesnych Polaków. [W:] A. Żurek (red.), Człowiek i jego religijność (s. 161-173). Tarnów: Byblos.

Szymołon, J. (2006). Przedmiot psychologii religii. [W:] S. Głaz (red.), Podstawowe zagadnienia psychologii religii (s. 42-49). Kraków: Wydawnictwo WAM.

Talik, E. (2008). Religijne i poza-religijne strategie radzenia sobie a poczucie kontrolowalności sytuacji stresowej u mtodzieży. Nie opublikowana praca doktorska, Instytut Psychologii, Katolicki Uniwersytet Lubelski Jana Pawła II, Lublin.

Tarakeshwar, N., Pargament, K. I., \& Mahoney, A. (2003). Initial development of a measure of religious coping among Hindus. Journal of Community Psychology, 31(6), 607-628.

Van Dyke, C. J., Glenwick, D. S., Cecero, J. J., \& Kim, S.-K. (2009). The relationship of religious coping and spirituality to adjustment and psychological distress in urban early adolescents. Mental Health, Religion and Culture, 12(4), 369-383.

Vijver, F. W., \& Hambleton, R. K. (1996). Translating tests: Some practical guidelines. European Psychologist, 1(2), 89-99.

Walesa, C. (2006). Rozwój religijności człowieka. W: S. Głaz (red.), Podstawowe zagadnienia psychologii religii (s.111-146). Kraków: Wydawnictwo WAM.

Wandrasz, M. (2006). Choroba i cierpienie a religijność. [W:] S. Głaz (red.), Podstawowe zagadnienia psychologii religii (s. 511-532). Kraków: Wydawnictwo WAM.

Watlington, C. G., \& Murphy, C. M. (2006). The roles of religion and spirituality among African American survivors of domestic violence. Journal of Clinical Psychology, 62(7), 837-857.

Wills, T. A., Yaeger, A. M., \& Sandy, J. M. (2003). Buffering effect of religiosity for adolescent substance use. Psychology of Addictive Behaviors, 17, 24-31.

Winter, U., Hauri, D., Huber, S., Jenewein, J., Schnyder, U., \& Kraemer, B. (2009). The psychological outcome of religious coping with stressful life events in a Swiss sample of church attendees. Psychotherapy and Psychosomatics, 78(4), 240-247.

Yoshimoto, S. M., Ghorbani, S., \& Baer, J. M. (2006). Religious coping and problem-solving by couples faced with prostate cancer. European Journal of Cancer Care, 15(5), 481-488.

Zwingmann, C., Müller, C., Körber, J., \& Murken, S. (2008). Religious commitment, religious coping and anxiety: A study in German patients with breast cancer. European Journal of Cancer Care, 17(4), 361-370. 